\title{
The industry effects of monetary policy in Spain
}

\author{
Carlos J. Rodriguez-Fuentes \\ Department of Applied Economics \\ University of La Laguna \\ e-mail: cjrodrig@ull.es \\ David Padrón-Marrero \\ Department of Applied Economics \\ University of La Laguna \\ e-mail:dpadron@ull.es
}

\begin{abstract}
The aim of this paper is to analyze the presence of sectoral asymmetries in monetary policy transmission in Spain in the period prior to the introduction of the single monetary policy in Europe (1988-1998). Monetary policy shocks are identified both through a standard vector auto-regression model (VAR-shock) and the specification of a reaction function (RF-shock) for the monetary authority in Spain. The responses of the different industrial branches with regard to the estimated monetary shocks are then analyzed at national accounting sector and sub-sector levels. Our results confirm the presence of significant differences in the sectoral responses with respect to national monetary shocks in Spain. In addition, the sectoral asymmetries found in our study show a strong correlation with regard to the regional asymmetries found in a previous study (Rodríguez Fuentes et al. 2004)
\end{abstract}

Key words: monetary policy; sectoral effects; VAR models; reaction functions

Subject Area: European economy, Spanish economy 


\section{Introduction.}

The study of the transmission mechanism of monetary policy has traditionally focused on the aggregate level of the economy, specifically on the impact of monetary policy decisions on production and price levels. Nevertheless, the last decade has seen an increasing amount of research which concentrate on the study of asymmetries which can arise in the transmission of national monetary shocks, either in specific regions which make up the national economy (regional asymmetries), or among their respective productive sectors (sectoral asymmetries). Undoubtedly a significant portion of this literature is motivated by the loss of monetary sovereignty which some European Union (EU) countries have experienced as a result of their conversion into regions within the eurozone. These countries have all irreversibly lost their prior "national monetary identities" and as such have begun to be concern about the regional repercussions of the European Central Bank's monetary policy (Rodríguez Fuentes 2005: 5-7).

The growing interest in the study of sectoral asymmetries in the transmission of monetary policy has also been stimulated by the forecast that the establishment of a single currency in the European Union would convert sectoral shocks in truly regional shocks (Krugman and Venables 1996), which in turn would lead to regional tensions in the process of European integration. ${ }^{1}$ This forecast has also been reinforced by some empirical evidence in studies which emphasize the importance of the differences in the regional productive structure in the explanation of the different regional responses with regard to national monetary policy shocks (see, among others, Carlino and DeFina 1996, 1998a, 1998b and 1999, Guiso et al. 1999 and Arnold, 2001).

This paper sectoral asymmetries in the transmission of national monetary shocks in Spain and also explores possible relationships among estimated sector shocks with the estimated regional shocks from an earlier one (Rodríguez Fuentes et al. 2004).

\footnotetext{
${ }^{1}$ Nevertheless, this hypothesis has been questioned by other authors, who point out that the shape of a monetary union also reinforces bilateral trade among its members. This effect would result in higher
} 
The paper is divided into an introduction, four main sections and conclusions. The body of the paper begins with a brief review of the empirical literature concerning sectoral asymmetries in monetary policy transmission. The responses of the different branches which make up the industrial sector in Spain are then studied in the next two sections. Section 3 introduces the estimates of monetary policy shocks in Spain for the period 1988-1998. It is well known that the estimation of monetary shocks is a critical step in any study which attempts to analyze the effects of monetary policy, and that the observed correlations between interest rates, output and prices can be due to an inverse causation process. Consequently the exogenous component (monetary shocks) must be isolated from its endogenous response. A VAR model is used to identify these shocks. Most empirical literature employs the VAR model when studying the monetary transmission mechanism. However our study does not end with just the VAR model. In addition we estimate a reaction function for the Bank of Spain in order to compare the robustness of the results obtained from our VAR model. This new approach can be used, in our opinion, as a complement to the traditional VAR literature. Section 4 studies the response of industrial production (by sector and sub-sector) with regard to the estimated monetary policy shocks from the previous section. Our results confirm the presence of important differences in the sectoral responses with respect to national monetary shocks in Spain and are consistent with available empirical evidence of other countries. In addition the sectoral asymmetries presented in this section show some similarities with the regional asymmetries found in a previous work (Rodríguez Fuentes et al. 2004) since the classification of the Spanish regions according to their implicit sectoral sensitiveness reflect a strong correlation with the ordering which is obtained by using their sensitivity when taking into account national monetary shocks (regional asymmetries).

levels of correlation in their respective cycles and a lower probability of experiencing asymmetric shocks (Frankel and Rose 1998). 


\section{Sectoral asymmetries in the transmission of monetary policy: an overview of the empirical literature.}

A review of the literature on the sectoral effects of monetary policy based on empirical evidence, leads to three important conclusions. Firstly, the choice of the VAR model as the econometric technique to identify monetary shocks. Secondly, that the strategy followed to value the measure of heterogeneity in the sectoral response consists in estimating a VAR model for each one of the sectors studied. This strategy leads to estimating as many reaction functions as sectors that are considered in the study and, consequently, obtaining a series of different monetary shocks ${ }^{2}$ for each one of the studied sectors (which hinders the validity of intersectoral comparisons). The third conclusion is that most studies tend to incorporate among the endogenous variables both national and sectoral variables (production and price levels). In this case it is more common that national aggregates are placed ahead of the monetary policy variable, while sectoral variables appear after that variable (see Ganley and Salmon 1997 and Dedola and Lippi 2000 and 2005). This consideration and the use of recursive identification methods (Cholesky decomposition method) lead to the inclusion of the implicit assumption that monetary shocks do not have a contemporaneous impact on national aggregates but do have an instantaneous effect on sectoral variables, which could be interpreted as an inconsistency in the model. ${ }^{3}$

This analysis is found in works by Ganley and Salmon (1997) which studies the responses of different production sectors with respect to monetary policy shocks in the United Kingdom. This study estimates 24 VAR models (one for each one of the sectors under study) which incorporate, as endogenous variables, short term interest rate, the real GNP of the United Kingdom and its implicit deflactor and, lastly, the production index of each sector. The Cholesky decomposition method is used with the variables ordered according to their previously mentioned description. Results

\footnotetext{
${ }^{2}$ This result is unconvincing since Central Bank decisions will always cause a single (and common) monetary shock, which undoubtedly might produce different effects on certain sectors; but it is the response that might differ across sectors not the shock itself.

${ }^{3}$ Nevertheless, Dedola and Lippi (2005: 1551) point out that, the estimated parameter associated with the instantaneous response of the production sector monetary shock is not far from zero, and such an inconsistency would not be relevant in its model.
} 
from the study indicate that monetary policy measures implemented by the Bank of England have had varying impacts according to sectors. Examples can be found in the construction sector, and to a lesser extent, in manufacturing, where both sectors are subject to stronger and more rapid responses to national monetary shocks. In addition, the authors confirm large variability in the response to each one of branches that make up the manufacturing sector. For instance there are cases where some branches offer a very weak response (industries linked to non-durables consumer expenditures, as producers of food, drink and tobacco, textiles and footwear), while other industries (industries supplying construction, as glass, tiles, concrete and bricks, and wood products; or industries linked to durables consumer expenditures, as vehicle manufacture) react in a very clear manner.

Results obtained by Hayo and Uhlenbrock (2000) also suggest the presence of important sectoral differences in their responses to national monetary shocks in West Germany. Their findings show that approximately half of the analyzed branches show a different response than the average one for the sector.

Dedola and Lippi (2000 and 2005) focus on the responses of industrial production in five countries belonging to the OECD. They study the production sector response of 21 industrial branches in Germany, France, U.S., Italy and the United Kingdom by using a common specification in the estimated VAR models. The results from these papers indicate that the differences among sectoral responses with respect to monetary shocks are much greater than those found in other countries. The authors also investigated if the observed sector heterogeneity in the response to national monetary shocks was due to industry-specific factors or country-specific factors. They concluded that sectoral responses were similar among all of the different countries studied. Their results also showed that the impact of monetary shocks is greater in production industries including durable goods, which place greater demands on working capital and smaller borrowing capacity (Dedola y Lippi, 2005: 1565).

As noted earlier, most of the empirical studies which analyze sectoral effects of monetary policy tend to employ a VAR model to estimate each sector's response. 
This decision also assumes that national variables are not instantaneously affected by monetary shocks whereas the sectoral variables are, which could be interpreted as an inconsistency in the model. Various alternatives have been proposed to address this inconsistency. One is seen in Raddatz and Rigobon (2003), where the authors suggest estimating a single national VAR model, where national production is substituted by the production levels in each sector under consideration. These authors also introduce a non recursive identification method which allows them to sort the obstacle, namely that monetary shocks do not have a contemporaneous effect on national variables but do have an instantaneous effect on sectoral variables. Even so, the results obtained by Raddatz and Rigobon (2003) also suggest the presence of important sectoral asymmetries in the responses from different industrial branches in the U.S. economy with respect to national monetary policy, where durable goods and property investment are the two sectors that show the strongest response. Nevertheless, the approach by Raddatz and Rigobon (2003) is not problem-free. For instance, the complete identification of all structural parameters of the model requires several assumptions. In addition the large number of estimated parameters creates an important reduction in the degrees of freedom, a sensitive issue when working with short time series.

Peersman and Smets (2002) propose a two-step strategy to value sectoral asymmetries in monetary policy transmission in the euro zone. The first stage is carried out by extracting monetary shocks from the estimates derived from a VAR model for the national economy. The estimated national monetary shocks from the first stage are then used in the second stage to explain the behaviour of the sectoral production based upon its past behaviour and estimated national monetary shocks from the prior stage. These estimated national monetary shocks will be equal for each one of the studied sectors since they have been extracted from the national VAR model.

We begin our study by incorporating the strategy used in Peersman and Smets (2002) but will also estimate national monetary shocks by using the specification of a reaction function for the Bank of Spain. 


\section{Identification of monetary shocks: VAR models and reaction functions.}

As mentioned earlier, the identification of monetary shocks was carried out using a VAR model and also by estimating a reaction function for the Bank of Spain. This second approach is, in our opinion, a novel contribution in the context of empirical literature regarding sectoral asymmetries in the transmission of monetary policy. Details of the specification of the VAR model as well as the reaction function follow.

\subsection{VAR Model}

The general equation of the VAR model that we have chosen to identify the monetary policy shocks Spain is of the form:

$$
\left[\begin{array}{l}
X_{t} \\
Y_{t}
\end{array}\right]=\left[\begin{array}{ll}
A(L) & B(L) \\
C(L) & D(L)
\end{array}\right]\left[\begin{array}{l}
X_{t-1} \\
Y_{t-1}
\end{array}\right]+\left[\begin{array}{ll}
a & b \\
c & d
\end{array}\right]\left[\begin{array}{c}
e_{t}^{X} \\
e_{t}^{Y}
\end{array}\right]
$$

where $Y_{t}$ is the vector containing the endogenous variables of the system, all of which refer to the set representing the national economy. This set is made up of these variables in the following order, national industrial production index (IPI), the consumer price index $(\mathrm{CPI})$, the German inter-bank interest rate $\left(i_{\mathrm{AL}}\right)$, the M3 monetary aggregate, the interest rate for three month non-transferable deposits $\left(i_{\text {ESP }}\right)$ and the real effective exchange rate for the peseta (REER). ${ }^{4}$

$$
Y_{t}=\left[\begin{array}{llllll}
I P I_{t} & C P I_{t} & i_{A L} & M 3 & i_{E S P} & R E E R
\end{array}\right]^{\prime}
$$

We have also introduced an exogenous variable vector which includes a constant (const), a tendency (trend), and a world commodity price index (WCPI) to control possible external shocks.

\footnotetext{
${ }^{4}$ The reasoning behind the inclusion of the German interest is to acknowledge Spain's membership in the EMS and the "anchoring" role performed by the German economy with the EMS. We also considered the insertion of the M3 due to the importance attributed by the Bank of Spain to monetary aggregates (in its monetary strategy) during most of the period under study.
} 
$X_{t}=\left[\text { const trend } W C P I_{t}\right]^{\prime}$

The VAR model has been estimated in levels, which allows us to control the possible existence of cointegration. Almost all variables are expressed in logarithmic form, the exception being the interest rates. Data have been taken from the Monthly Statistical Bulletin of the Bank of Spain and the sample covers the period from January, 1988 to December, $1998 .^{5}$ The lag structure used in the model is two months, and the monetary policy shock that we have identified is a result of the Cholesky decomposition method, with the variables defined and ordered according to our earlier comments. ${ }^{6}$

Graph 1 depicts the impulse-response function of the most important variables, namely production and prices. This graph indicates that prices remain unaltered after an unexpected monetary policy shock, which could be justified by the high levels of price (and nominal wages) rigidity that have been traditionally seen in the Spanish economy. The case of production, however, is consistent with other studies, where monetary policy reaches its maximum impact on production on the seventh month after the unexpected monetary shock took place.

\footnotetext{
${ }^{5}$ The reasoning for using this period is to avoid the period of monetary instability present during the 70 's and early 80's, where monetary policy of the Bank of Spain (BS) focussed on the strict control of monetary aggregates. Starting with the mid 80 's the growing financial opening of the Spanish economy, with its membership in the EMS, and especially the liberalization process of the Spanish financial system created important changes in the strategy followed by the BS, resulting in the growing importance of interest rates in the execution of monetary policy. We chose 1988 as the beginning date for this second period, thus avoiding the important variability experienced in interest rates during 1987.

${ }^{6}$ By acting this way we assume unexpected monetary policy actions do not have an instantaneous impact on output (IPI) and prices (CPI).
} 
Graph 1. Function of impulse-response of industrial production and prices with respect to a monetary shock (one standard deviation)

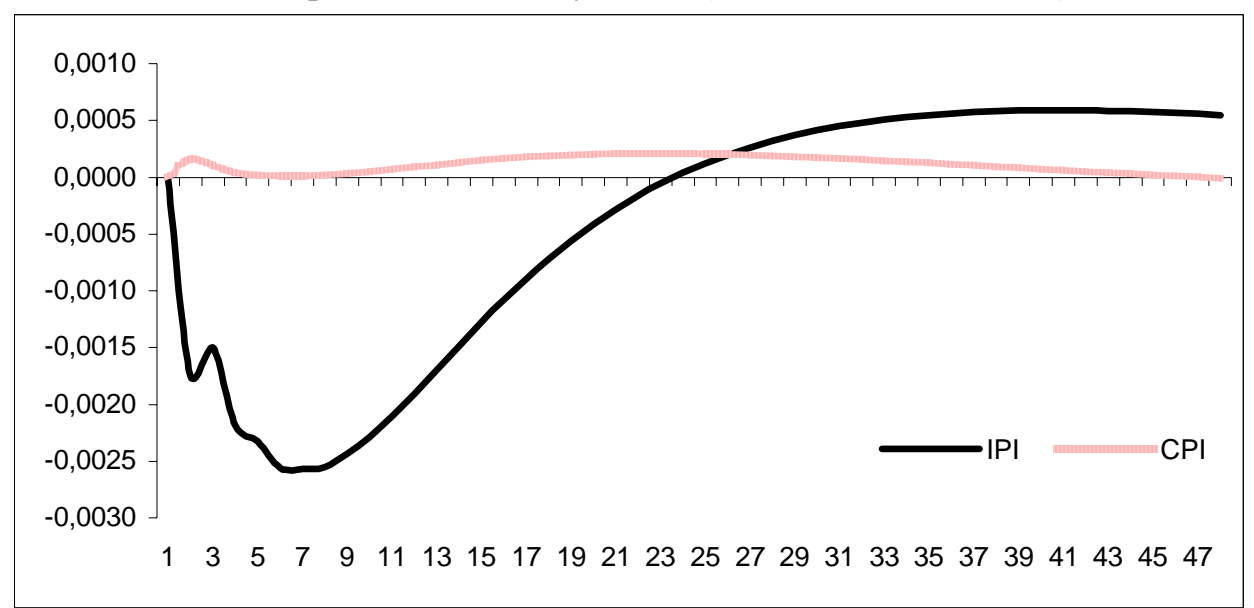

Note: The estimates were carried out using Eviews.

\subsection{Reaction function}

VAR methodology has played an important role in the empirical analysis concerning the impact of monetary policy actions on economy. Even so it has been questioned not only in its method for retrieving monetary shocks but also with the problems associated with capturing the forward-looking behaviour which modern monetary policy theory attributes to central banks (Clarida et al. 1999 and Svensson 1999). Under this scenario, the monetary authority considers the expected evolution of the relevant economic aggregates in the near future while making decisions in the present. This approach has grown in favour among a number of authors when evaluating the actions of central banks, and can be adapted to its inclusion in the specification of a reaction function for the monetary authority.

For this reason we also decided to estimate a reaction function for the Bank of Spain where the unexpected monetary shock is identified with the unexplained observed interest rates by deriving rates based on the estimated reaction function.

The reaction function that we estimated has the following form:

$$
\left.\mathrm{i}_{\mathrm{i}}=\rho \mathrm{i}_{\mathrm{t}-1}+(1-\rho) \mid \alpha+\beta \pi_{\mathrm{t}+\mathrm{k}}+\gamma \mathrm{x}_{\mathrm{t}+\mathrm{p}}+\lambda \mathrm{Z}_{\mathrm{t}}\right\rfloor+\varepsilon_{\mathrm{t}}
$$


where $\pi$ is the interannual inflation rate, $\mathrm{x}$ is the output-gap, and $\mathrm{Z}$ represents a set of variables which can affect interest rate decisions, independently of its explanatory power on inflationary trends and the output-gap, which include the exchange rate and a foreign interest rate. Our model specification includes the peseta/mark nominal exchange rate and the German three month interest rate.

The proposed reaction function is a simple combination of a Taylor Rule type reaction function (Taylor 1993) and a first order partial autoregression rule. The Taylor Rule reaction function incorporates the forward-looking behaviour assumption for the monetary authority (under the assumption of rational expectations). The autoregression rule captures demonstrated tendencies by central banks to smoothen interest rate changes.

The resultant reaction function was estimated by the Generalized Method of Moments (GMM) by taking advantage of the following set of orthogonal conditions:

$$
\mathrm{E}\left[\varepsilon_{\mathrm{t}} / \Omega_{\mathrm{t}}\right]=\mathrm{E}\left[\mathrm{i}_{\mathrm{t}}-\rho \mathrm{i}_{\mathrm{t}-1}-(1-\rho)\left[\alpha+\beta \pi_{\mathrm{t}+\mathrm{k}}+\gamma \mathrm{x}_{\mathrm{t}+\mathrm{p}}+\lambda \mathrm{Z}_{\mathrm{t}}\right] / \Omega_{\mathrm{t}}\right]=0
$$

Possible problems of heterokedasticity and autocorrelation led us to use the Newey and West method when calculating standard errors. The Hansen J statistic was also calculated to control possible overidentification. Table 1 shows that the best results were obtained by the forecast horizon $\mathrm{k}=6 \cap \mathrm{p}=3$. In addition we decided to omit the peseta/mark nominal exchange rate since changes in the variable were not statistically significant in any of the tested specifications. 
Table 1. Results from estimating the reaction function for the Bank of Spain

\begin{tabular}{|c|c|c|c|c|c|c|c|c|}
\hline & $\begin{array}{l}\mathrm{k}=3 \\
\mathrm{p}=3\end{array}$ & $\begin{array}{l}\mathrm{k}=6 \\
\mathrm{p}=6\end{array}$ & $\begin{array}{l}\mathrm{k}=12 \\
\mathrm{p}=12\end{array}$ & $\begin{array}{l}\mathrm{k}=6 \\
\mathrm{P}=3\end{array}$ & $\begin{array}{c}\mathrm{k}=12 \\
\mathrm{p}=3\end{array}$ & $\begin{array}{c}\mathrm{K}=12 \\
\mathrm{p}=6\end{array}$ & $\begin{array}{c}\mathrm{k}=3 \\
\mathrm{p}=3 \\
\mathrm{Z}=\mathrm{i}_{\mathrm{AL}}\end{array}$ & $\begin{array}{c}\mathrm{k}=6 \\
\mathrm{p}=3 \\
\mathrm{Z}=\mathrm{i}_{\mathrm{AL}}\end{array}$ \\
\hline$\rho$ & $0,905 * *$ & $0,949 * *$ & $0,973 * *$ & $0,924 * *$ & $1,006 * *$ & 1002 & $0,898 * *$ & $0,897 * *$ \\
\hline$\alpha$ & $-0,485$ & $-2,015$ & $-0,249$ & $-1,943 *$ & 33,049 & 81,290 & $-0,414$ & $-1,204$ \\
\hline$\beta$ & $2,054 * *$ & $2,556^{* *}$ & $1,532^{* *}$ & $2,252 * *$ & $-0,700$ & $-4,583$ & $1,895^{* *}$ & $1,523 * *$ \\
\hline$\gamma$ & $0,223 * *$ & 0,088 & $-0,337 *$ & $0,423 * *$ & $-2,662$ & $-3,986$ & $0,205^{* *}$ & $0,226^{* *}$ \\
\hline$\lambda$ & - & - & - & - & - & - & 0,122 & $0,561 * *$ \\
\hline $\mathrm{R}^{2}$ & & 0,985 & & 0,983 & 0,982 & 0,982 & 0,986 & 0,985 \\
\hline S.E. & 0,419 & 0,424 & 0,444 & 0,458 & 0,439 & 0,443 & 0,419 & 0,433 \\
\hline I-test & 17,12 & 17,32 & 16,69 & 17,60 & 17,22 & 17,39 & 16,99 & 17,75 \\
\hline J-test & {$[0,998]$} & {$[0,998]$} & {$[0,998]$} & {$[0,997]$} & {$[0,998]$} & {$[0,997]$} & {$[0,997]$} & {$[0,995]$} \\
\hline
\end{tabular}

Note: The estimates were carried out using Eviews.

$*$ and $* *$ denotes that a variable is significant at the 5 and $1 \%$ level, respectively.

The following variables were used in the estimation: constant, $\mathrm{i}_{\mathrm{t}-1}, \mathrm{i}_{\mathrm{t}-2}, \mathrm{i}_{\mathrm{t}-3}, \mathrm{i}_{\mathrm{t}-4}, \mathrm{i}_{\mathrm{t}-5}, \mathrm{i}_{\mathrm{t}-6}, \mathrm{i}_{\mathrm{t}-9}, \mathrm{i}_{\mathrm{t}-12}, \pi_{\mathrm{t}-1}, \pi_{\mathrm{t}-2}$, $\pi_{\mathrm{t}-3}, \pi_{\mathrm{t}-4}, \pi_{\mathrm{t}-5}, \pi_{\mathrm{t}-6}, \pi_{\mathrm{t}-9}, \pi_{\mathrm{t}-12}, \mathrm{x}_{\mathrm{t}-1}, \mathrm{x}_{\mathrm{t}-2}, \mathrm{x}_{\mathrm{t}-3}, \mathrm{x}_{\mathrm{t}-4}, \mathrm{x}_{\mathrm{t}-5}, \mathrm{x}_{\mathrm{t}-6}, \mathrm{x}_{\mathrm{t}-9}, \mathrm{x}_{\mathrm{t}-12}, \mathrm{q}_{\mathrm{t}-1}, \mathrm{q}_{\mathrm{t}-2}, \mathrm{q}_{\mathrm{t}-3}, \mathrm{q}_{\mathrm{t}-4}, \mathrm{q}_{\mathrm{t}-5}, \mathrm{q}_{\mathrm{t}-6}, \mathrm{q}_{\mathrm{t}-9}, \mathrm{q}_{\mathrm{t}-12}, \mathrm{~m}_{\mathrm{t}-1}$, $\mathrm{m}_{\mathrm{t}-2}, \mathrm{~m}_{\mathrm{t}-3}, \mathrm{~m}_{\mathrm{t}-4}, \mathrm{~m}_{\mathrm{t}-5}, \mathrm{~m}_{\mathrm{t}-6}, \mathrm{~m}_{\mathrm{t}-9}, \mathrm{~m}_{\mathrm{t}-12}$. Where $\mathrm{q}$ is the change in the nominal peseta-mark exchange rate and $\mathrm{m}$ is the rate of growth in the M3 monetary aggregate. The table also shows the J-statistic and the probability of accepting the null hypothesis.

Graph 2 compares the accumulated monetary shocks obtained from VAR models with those derived from the reaction function. The resultant time profiles indicate that both series are quite similar, leading to an interpretation of favourable evidence regarding the robustness of our results. It is also worth mentioning the presence of a strong relationship between the shown path from the accumulated shocks and the short term interest rate. Consequently in the periods where the short term interest rate increases contracting shocks are seen, as in the opposite case for falling rates. Nevertheless, from 1996 to 1997 this relationship seems to stray from this trend. If this is the case these actions could be interpreted as deliberate actions by the Bank of Spain to tighten monetary policy and thus exercise stricter control on the inflation rate and satisfy the Maastricht criteria. 
Graph 2. Monetary shocks and short term interest rates in Spain

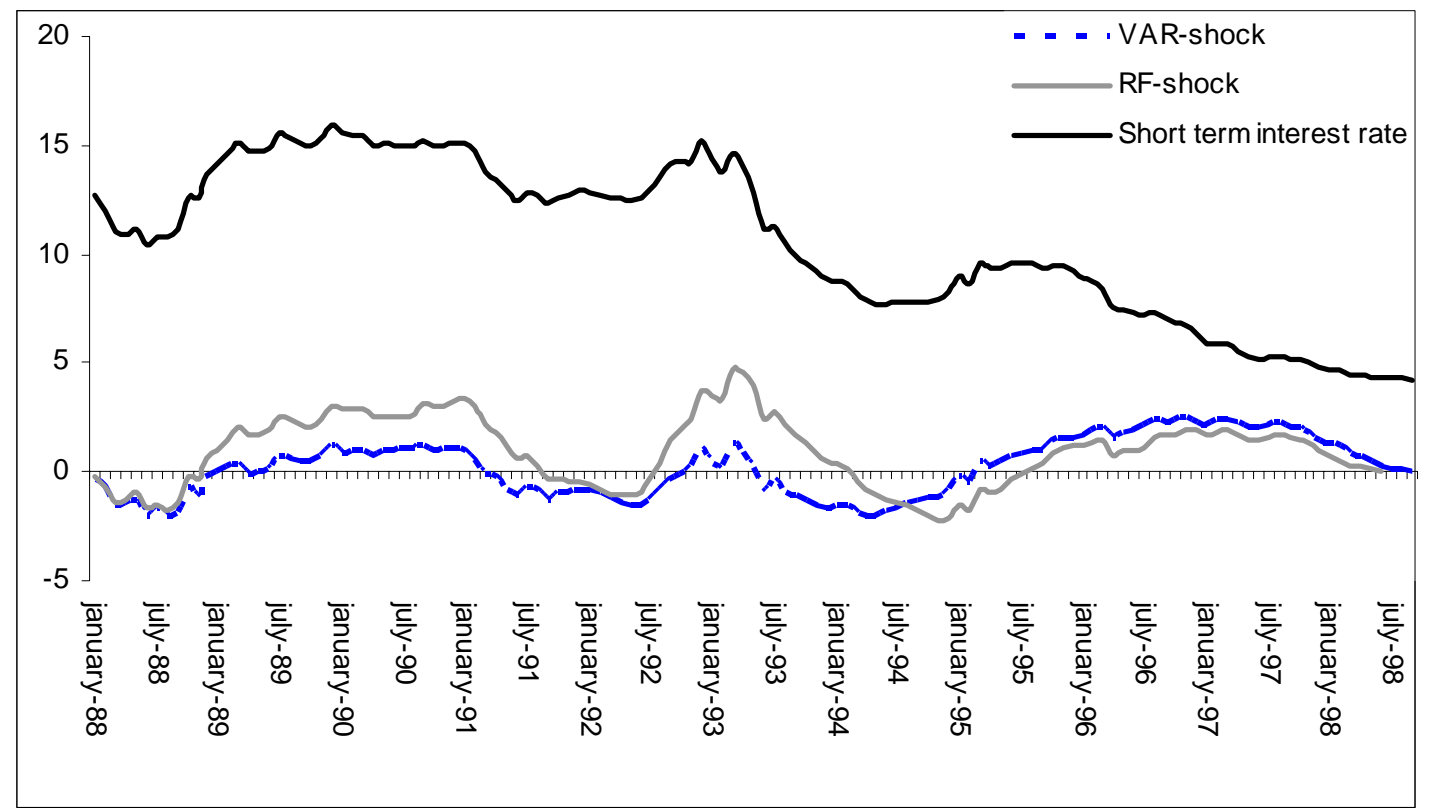

\section{Sectoral asymmetries in the transmission of monetary shocks.}

Following Peersman and Smets (2002), we study the industry effects of monetary policy shock in Spain $^{7}$ by using the following expression which relates the trends from the production activity from each industrial branch with its past behaviour and the estimated accumulated monetary shock from the prior section:

$\mathrm{ipi}_{\mathrm{i}, \mathrm{t}}=\alpha_{\mathrm{i}}+\sum_{\mathrm{j}=1}^{12} \beta_{\mathrm{i}} \cdot \mathrm{ipi}_{\mathrm{i}, \mathrm{t}-\mathrm{j}}+\gamma_{\mathrm{i}} \cdot \operatorname{shock}_{\mathrm{t}-1}+\eta_{\mathrm{i}, \mathrm{t}}$

where ipi $_{\mathrm{i}, \mathrm{t}}$ is monthly growth rate of the Industrial Production Index (IPI) of branch $\mathrm{i}$, shock $_{\mathrm{t}-1}$ is the accumulated monetary policy shock estimated previously (VAR-shock and RF-shock) and $\eta_{i, t}$ is an error term. Given the possibility of instantaneous correlation between the different Spanish industrial branches, expression (6) has been estimated using the SUR (Seemingly Unrelated Regressions) method.

\footnotetext{
${ }^{7}$ Data restrictions limit the estimates for the industrial activity branches to the period 1991-1998.
} 
Table 2 summarizes the estimated values from the response of the different industrial sections in Spain with respect to a monetary shock $\left(\gamma_{i}\right)$. This table indicates that the production response with respect to an unexpected monetary shock is generally negative. Another aspect which deserves our attention is the presence of clear similarities among the obtained results for both VAR and RF shocks. These results suggest that the contraction in production is greater among mining industries (section C), while section E (Electricity, gas and water supply) are found at the opposite extreme. However, the low statistical significance of the estimates for this disaggregated level (sections) should be highlighted, since only the estimated response for the mining industries from the RF-shock were seen to be statistically significant.

Table 2.- Response from different industrial branches with respect to a monetary shock $\left(\gamma_{\mathrm{i}}\right)$

\begin{tabular}{|c|c|c|c|c|c|}
\hline \multicolumn{3}{|c|}{ RF-shock } & \multicolumn{3}{c|}{ VAR-shock } \\
\hline Section & Coeficient & t-statistic & Section & Coeficient & t-statistic \\
\hline C & $-1,260707$ & $-2,648278$ & C & $-0,665141$ & $-1,641380$ \\
\hline D & $-0,490532$ & $-1,509285$ & D & $-0,229419$ & $-0,973417$ \\
\hline E & $-0,025145$ & $-0,103596$ & E & 0,221215 & 0,869998 \\
\hline
\end{tabular}

The lack of statistical significance from the obtained results at the section level of industrial activity could be attributed to the presence of distinct behaviour among the activity branches (subsections) which make up the different industrial sections. We therefore proceed to analyze the sectoral responses at the subsection level, with the results shown in table 3 .

The estimated parameters are generally characterized by an expected negative sign, indicating the (unexpected) tightening of monetary policy resulting in a contraction of the different industrial branches under study. The results also indicate once again that estimated parameters from the RF-shock are greater (in absolute value) than those obtained from using the VAR-shock, in addition to having greater statistical significance. Although there is a greater level of disaggregation in these estimates, the comparison between the obtained sectoral responses from both VAR and RF shocks allow us to offer some conclusions. Firstly, that subsection EA (electricity, gas and water supply) once again is seen as one of the branches least sensitive to 
monetary shocks, as in the case at the section level. Other branches also appear, such as the manufacture of food products, beverages and tobacco (subsection DA), as well as the manufacture of leather and leather products (subsection DC), the paper industry (subsection DE) and the manufacture of coke, refined petroleum products and nuclear fuels (subsection DF). Another observation is that the greater sensitivity to national monetary shocks would take place in machinery and mechanical equipment (subsection DK), the mining and quarrying of energy producing material (subsection $\mathrm{CA}$ ) and the mining and quarrying of other minerals (subsection $\mathrm{CB}$ ).

Table 3.- Response by industrial subsections with respect to monetary shock $\left(\gamma_{\mathrm{i}}\right)$

\begin{tabular}{|c|c|c|c|c|c|}
\hline \multicolumn{3}{|c|}{ FR-shock } & \multicolumn{3}{|c|}{ VAR-shock } \\
\hline Subsection & Coeficient & t-statistic & Subsection & Coeficient & t-statistic \\
\hline $\mathrm{DA}$ & 0,107995 & 0,367364 & EA & 0,245455 & 0,968357 \\
\hline $\mathrm{DC}$ & $-0,032593$ & $-0,082099$ & $\mathrm{DN}$ & 0,208370 & 0,460732 \\
\hline EA & $-0,051506$ & $-0,213997$ & DF & 0,070817 & 0,185372 \\
\hline DE & $-0,081628$ & $-0,342259$ & DE & $-0,033691$ & $-0,139498$ \\
\hline DF & $-0,224908$ & $-0,668028$ & $\mathrm{DA}$ & $-0,090756$ & $-0,293388$ \\
\hline $\mathrm{DG}$ & $-0,292967$ & $-0,733748$ & $\mathrm{DC}$ & $-0,095969$ & $-0,228702$ \\
\hline DI & $-0,412020$ & $-1,659494$ & $\mathrm{DH}$ & $-0,276524$ & $-0,644695$ \\
\hline $\mathrm{DN}$ & $-0,537933$ & $-1,236804$ & DI & $-0,314554$ & $-1,506139$ \\
\hline $\mathrm{DL}$ & $-0,823875$ & $-1,465081$ & DJ & $-0,339709$ & $-1,129706$ \\
\hline $\mathrm{DD}$ & $-0,861333$ & $-1,646532$ & DM & $-0,391174$ & $-0,435383$ \\
\hline $\mathrm{DB}$ & $-0,948324$ & $-2,477780$ & DL & $-0,515330$ & $-0,896411$ \\
\hline $\mathrm{DH}$ & $-1,088006$ & $-2,424762$ & $\mathrm{DG}$ & $-0,535510$ & $-1,533995$ \\
\hline DJ & $-1,090333$ & $-2,990396$ & DB & $-0,551075$ & $-1,706137$ \\
\hline $\mathrm{CB}$ & $-1,126873$ & $-1,988770$ & $\mathrm{DD}$ & $-0,630545$ & $-1,298233$ \\
\hline $\mathrm{CA}$ & $-1,560122$ & $-3,520476$ & $\mathrm{CA}$ & $-0,715491$ & $-1,580320$ \\
\hline DK & $-1,925580$ & $-3,067467$ & $\mathrm{CB}$ & $-0,819522$ & $-1,629274$ \\
\hline $\mathrm{DM}$ & $-2,002185$ & $-2,523202$ & DK & $-1,111361$ & $-2,136371$ \\
\hline \multicolumn{3}{|c|}{$\begin{array}{l}\mathrm{CA}=\text { Mining and quarrying of energy producing } \\
\text { materials } \\
\mathrm{CB}=\text { Mining and quarrying, except of energy } \\
\text { producing materials } \\
\mathrm{DA}=\text { Manufacture of food products, beverages } \\
\text { and tobacco } \\
\mathrm{DB}=\text { Manufacture of textiles and textile products } \\
\mathrm{DC}=\text { Manufacture of leather and leather products } \\
\mathrm{DD}=\text { Manufacture of wood and wood products } \\
\mathrm{DE} \text { = Manufacture of pulp, paper and paper } \\
\text { products; publishing and printing } \\
\mathrm{DF}=\text { Manufacture of coke, refined petroleum } \\
\text { products and nuclear fuel } \\
\text { DG = Manufacture of chemicals, chemical } \\
\text { products and man-made fibres }\end{array}$} & \multicolumn{3}{|c|}{$\begin{array}{l}\text { DH = Manufacture of rubber and plastic products } \\
\text { DI = Manufacture of other non-metallic mineral } \\
\text { products } \\
\text { DJ = Manufacture of basic metals and fabricated } \\
\text { metal products } \\
\text { DK = Manufacture of machinery and equipment } \\
\text { n.e.c. } \\
\text { DL = Manufacture of electrical and optical } \\
\text { equipment } \\
\text { DM = Manufacture of transport equipment } \\
\text { DN = Manufacting n.e.c. } \\
\text { EA = Electricity, gas and water supply }\end{array}$} \\
\hline
\end{tabular}


Some important differences need to be mentioned when comparing the results from the obtained estimates from the reaction function (RF-shock) and the VAR model (VAR-shock). The first difference concerns the DM (Manufacture of transport equipment) and DJ (Manufacture of basic metals and fabricated metal products) subsections. While high sensitivity is observed with respect to estimated monetary shocks based on the reaction function (RF-shock) of these subsections, the VARshock produces much lower sensitivity. A second difference occurs in the different manufacturing industries (subsection $\mathrm{DN}$ ), where slight sensitivity with respect to estimated monetary shocks based on the VAR model are noted (VAR-shock). Nevertheless, the estimated response for the reaction function (RF-shock) ranks this section in an intermediate position among all sectors.

The presence of sectoral asymmetries in the transmission of monetary policy has obvious direct implications at the regional level. Indeed, given that Spanish regions show important differences in industrial specialization, the presence of different sectoral responses with respect to monetary policy impulses in Spain could convert the sectoral shocks into regional ones. With the purpose of studying the link between sectoral asymmetries and regional asymmetries in Spain, we calculated an index of regional sensitivity (ISR-1) ${ }^{8}$ which, hypothetically, would reflect the sensitivity of each Spanish region with respect to the monetary shocks based on the industrial specialization profile. The comparison between this index, which reflects the regional sensitivity due to the region's industry-mix, and the regional response with respect to national monetary policy shocks ${ }^{9}$, which we estimated in an earlier work, indicates the presence of a high degree of correlation between regional and sectoral asymmetries in Spain (graph 3), which is consistent with the traditional literature regarding the interest rate transmission mechanism. Nevertheless, this correlation is far from being perfect, so it seems reasonable that other factors different to the sectoral-mix, such as those related to the financial structure and behaviour (see Rodríguez Fuentes et al. 2004: 260-262), may also have played a relevant role in the

\footnotetext{
${ }^{8}$ This parameter was calculated as the result of multiplying, for each region, the estimated sensitivity from the RF-shock (table 3) for each one of the industrial subsections by its respective participation in the regional industrial GDP in 1998.

${ }^{9}$ The values of both parameters are shown in Table 1 of the appendix.
} 
explanation of regional asymmetries in the transmission of monetary shocks in Spain.

Graph 3. Sectoral and regional asymmetries

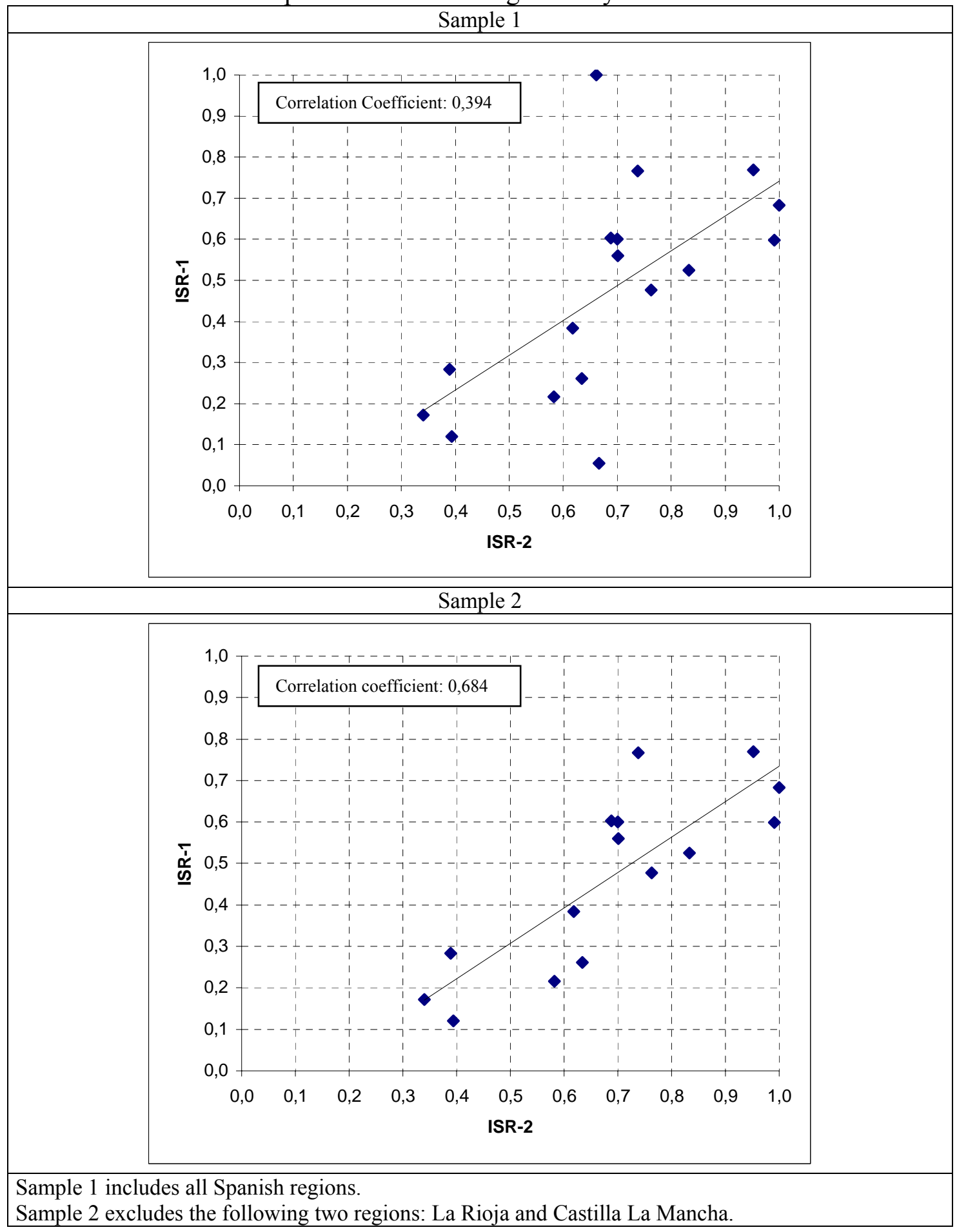




\section{Conclusions.}

This paper has studied sectoral asymmetries in the transmission of monetary policy shocks in Spain in the period immediately prior to the establishment of the single monetary policy (1988-1998). The identification of the monetary shocks was carried out through the estimate of a VAR model and the specification of a reaction function for the Bank of Spain. The monetary shocks obtained were then employed to study the degree of sensitivity of the different activities that make up the industrial sector in Spain. Our results are consistent with those available for other countries (Ganley and Salmon 1997, Dedola and Lippi 2000 and 2005, Hayo and Uhlenbrock 2000, Peersman and Smets 2002 and Raddatz and Rigobon 2003), namely the presence of important differences in sectoral responses with respect to national monetary shocks in Spain. In addition, the sectoral asymmetries found in our study show a strong correlation with the regional asymmetries found in a previous study (Rodríguez Fuentes et al. 2004). In particular, the resultant classification from ordering Spanish regions according to the sensitivity of different industrial branches which make up their respective industrial GDP reveals a high correlation with the ordering that is obtained by using sensitivity with respect to national monetary shocks (regional asymmetries). We can conclude from our results that at least during the period 19881998, differences in industrial specialization are an important explanatory factor for the regional asymmetries in the transmission mechanism of monetary policy in Spain. However, aside from the fact that the correlation among sectoral and regional shocks is less than one, we could also conclude that the explanation of the regional differences with respect to national monetary shocks requires the inclusion of different factors not found in regional productive specialization. Such factors would include those related with the dimension and financial structure of the regional business and financial sectors, as well as the levels of competition (both internal and external) which are present in each sector. 


\section{References}

Arnold, I. J. M. (2001), The Regional Effects of Monetary Policy in Europe, Journal of Economic Integration, 16 (3), pp. 399-420.

Arnold, I. J. M. and Vrugt (2002), Regional Effects of Monetary Policy in the Netherlands, International Journal of Business and Economics, 1 (2), pp. 123-134.

Arnold, I. J. M., Kool, C. J. M. and Raabe, K. (2005), New evidence on the firm size effects in US monetary policy transmission, Tjalling C. Koopmans Research Institute, Discussion Paper Series no 05-11.

Barth, M. J. and Ramey, V.A. (2001), “The cost channel of monetary transmisión”, in: Bernanke, B. and Rogoff, K (eds.), NBER Macroeconomic Annuals 2001, MIT Press, Cambridge, MA, pp. 199-240.

Bravo, H.F., García, C.J., Mies, V. and Tapia, M. (2003), Heterogeneidad de la transmisión monetaria: efectos sectoriales y regionales, Banco Central de Chile Working Paper $n^{\circ} 235$, October.

Carlino, G. and DeFina, R. (1996), Does monetary policy have differential regional effects? Federal Reserve Bank of Philadelphia, Business Review, March/April, pp. $17-27$.

Carlino, G. and DeFina, R. (1998a), The differential regional effects of monetary policy, Review of Economics and Statistics, 80 (4), pp. 572-587.

Carlino, G. and DeFina, R. (1998b), Monetary Policy and the U.S. States and Regions: Some Implications for the European Monetary Union, Federal Reserve Bank of Philadelphia, Working Paper no. 98-17. [reprinted in: von Hagen, J. y Waller, C.J. (2000), (eds.): Regional Aspects of Monetary Policy in Europe, Kluwer Academic Publishers, London.] 
Carlino, G. and DeFina, R. (1999), Do states respond differently to changes in monetary policy? Federal Reserve Bank of Philadelphia, Business Review, July/August, pp. 17-27.

Caruso, M. (2004), Monetary policy impulses, local output and the transmission mechanism, Banca D’Italia, Temi di Discussione no. 357, December.

Clarida, R., Galí, J. and Gertler, M. (1999), The science of monetary policy: a new Keynesian perspective, Journal of Economic Literature, 37(4): 1661-1707.

Dale, S. and Haldane, A. (1995), Interest Rates and the Channels of Monetary Transmission: Some Sectoral Estimates, European Economic Review, 39 (9), pp. 1611-1626.

Dedola, L. and Lippi, F. (2000), The monetary transmission mechanism: evidence from the industries of five OECD countries, CEPR, Discussion Paper no. 2508, July.

Dedola, L. and Lippi, F. (2005), The monetary transmission mechanism: evidence from the industries of five OECD countries, European Economic Review, vol. 49, pp. 1543-1569.

Farès, J. and Srour, G. (2001), The monetary transmission mechanism at the sectoral level, Bank of Canada, Working Paper no. 27, December.

Frankel, J.A. and Rose, A.K. (1998), The endogeneity of the Optimum Currency Area Criteria, Economic Journal, 108 (449), pp. 1009-1025

Fratantoni, M. (2003), Monetary Policy, Housing, and Heterogeneous Regional Markets, Journal of Money, Credit, and Banking, 35 (4), pp. 557-589.

Ganley, J. and Salmon, C. (1997), The industrial impact of monetary policy shocks: some stylized facts, Bank of England, Working Paper no. 68.

Guiso, L., A.K. Kashyap, F. Panetta and D. Terlizzese (1999), Will a Common European Monetary Policy Have Asymmetric Effects?, Federal Reserve Bank of Chicago, Economic Perspectives, fourth quarter, pp. 56-75. 
Hayo, B. and Uhlenbrock, B. (1999), Industry Effects of Monetary Policy in Germany, Center for European Integration Studies (ZEI), Working Paper B14, 1999. [reprinted in von Hagen, J. and Waller, C.J. (2000) (eds.): Regional Aspects of Monetary Policy in Europe, Kluwer Academic Publishers, London.]

Ibrahim, M.H. (2005), Sectoral Effects of Monetary Policy: Evidence from Malaysia, Asian Economic Journal, 19 (1), pp. 83-102.

Krugman, P. and Venables, A.J. (1996), Integration, specialization and adjustment, European Economic Review, vol. 40, pp. 959-967.

Mies, V.; Morandé, F. and Tapia, M. (2002), Política monetaria y mecanismos de transmission: nuevos elementos para una vieja discusión, Banco Central de Chile, Working Paper no. 181, September.

Peersman, G. and Smets, F. (2002), The industry effects of monetary policy in the Euro Area, European Central Bank, Working Paper no. 165. [also published in Economic Journal, vol. 115, April, pp. 319-342.]

Raddatz, C. and Rigobon, R. (2003), Monetary policy and sectoral shocks: did the FED react properly to the High-Tech Crisis?, Mimeo.

Rodríguez Fuentes, C.J. (2005), Regional Monetary Policy, Routledge: London.

Rodríguez Fuentes, C.J.; Padrón Marrero, D. and Olivera Herrera, A. (2004), Estructura financiera regional y política monetaria. Una aproximación al caso español, Papeles de Economía Española, no. 101, pp. 252-265.

Serju, P. (2003), Monetary policy and the Jamaican economy: a sectoral analysis, Bank of Jamaica, Research Service Department, Working Paper no. 02/09.

Svensson, L. (1999), Monetary policy issues for the eurosystem, Seminar Paper no. 667, Institute for International Economic Studies.

Taylor, J.B. (1993), Discretion versus policy rules in practice, Carnegie-Rochester Conference Series on Public Policy, 39: 195-214. 
Zucardi Huertas, I.E. (2002), Efectos regionales de la política monetaria en Colombia, Banco de la República de Colombia, Centro de Estudios Económicos Regionales, Working Paper on Regional Economics no. 32, July. 


\section{Appendix}

Table 1.- Sectoral and regional asymmetries of monetary policy in Spain

\begin{tabular}{|l|c|c|}
\hline & ISR-1 & ISR-2 \\
\hline Andalucia & 0,58 & 0,22 \\
\hline Aragon & 0,99 & 0,60 \\
\hline Asturias & 0,83 & 0,52 \\
\hline Baleares & 0,39 & 0,12 \\
\hline Canarias & 0,39 & 0,28 \\
\hline Cantabria & 0,70 & 0,56 \\
\hline Castilla-Leon & 0,74 & 0,77 \\
\hline Castilla-Mancha & 0,67 & 0,06 \\
\hline Cataluña & 0,70 & 0,60 \\
\hline Extremadura & 0,34 & 0,17 \\
\hline Galicia & 0,76 & 0,48 \\
\hline Madrid & 0,62 & 0,38 \\
\hline Murcia & 0,63 & 0,26 \\
\hline Navarra & 1,00 & 0,68 \\
\hline Pais Vasco & 0,95 & 0,77 \\
\hline Rioja & 0,66 & 0,60 \\
\hline Valencia & 0,69 & \\
\hline Correlation coefficient (1) & \multicolumn{2}{|c|}{0,394} \\
\hline Correlation coefficient (2) & \multicolumn{2}{|c|}{0,684} \\
\hline ISR-1: Thindex is
\end{tabular}

ISR-1: This index is the result of multiplying, for each region, the estimated sensitivity from the RF-shock (table 3) for each one of the industrial subsections by its respective participation in the regional industrial GDP in 1998. The values shown in the table are the result of diving each region's response by the maximum value.

ISR-2: The index reflects the response of the regional industrial production to unexpected monetary policy from a reaction function for the Bank of Spain (further details in Rodríguez Fuentes et al., 2004, p. 260). The values shown in the table are the result of diving each region's response by the maximum regional response.

(1) Including all regions.

(2) Excluding La Rioja and Castilla-La- Mancha. 